\title{
POTENTIAL PROTECTIVE ROLE OF SELENIUM ON ACRYLAMIDE-INDUCED OXIDATIVE STRESS IN RATS: A BIOCHEMICAL, HISTOPATHOLOGICAL STUDY
}

\author{
Eman A.A. Abdallah ${ }^{1}$ and Mai M. Abdelwahab ${ }^{2}$ \\ ${ }^{1}$ Department of Forensic Medicine and Clinical Toxicology \\ ${ }^{2}$ Department of pathology \\ Faculty of Medicine, Zagazig University. Alsharqia, Egypt.
}

\begin{abstract}
Background: Acrylamide (ACR) is an essential chemical which is extensively used in many industries and also in laboratories such as treatment of drinking water, waste water and soil, production of paper, petroleum, mine, asphalt, dyes, adhesives and polishes; it is known as possible carcinogenic compound. French fries, commercially common chips and all carbohydrate containing diet are rich in acrylamide. In this study when Acrylamide is taken into the body, we investigated its toxic effect on body organs and investigated the protective role of selenium. Aim: The aim of this work is to detect acrylamide effects on liver and kidney of adult male albino rats and assess the protective role of selenium. Material and methods: Acrylamide was administrated orally at dose of $(15 \mathrm{mg} / \mathrm{kg}$ body weight) (1/10 LD 50) daily for 8 weeks. Biochemical parameters in serum were studied: aspartate-aminotransferase (AST), alanine-aminotransferase (ALT), total protiens, Albumin, Globulin, urea, creatinine, and uric acid. Liver and kidneys will be examined by light microscope to evaluate histopathological changes. Tissue malondialdehyde (MDA) was done. Results: The results after being statistically analyzed and tabulated revealed that oral Acrylamide adminstration showed a highly significant $(\mathrm{P}<0.001)$ elevation in aspartateaminotransferase (AST), alanine-aminotransferase (ALT), a highly significant $(\mathrm{P}<0.001)$ decrease in serum total protiens, albumin, globulin and highly significant $(\mathrm{P}<0.001)$ decrease in serum urea, creatinine, and uric acid levels comparing to control group. Light microscope examination of the hepatic tissue in acrylamide treated group showed obvious congestion associated with wide spread marked vacuolar degeneration and kidneys showed marked congestion, marked hydropic degeneration of tubular epithelium and focal prominent tubular necrosis. There was a highly significant $(\mathrm{P}<0.001)$ increase in malondialdehyde level in acrylamide treated group comparing to control group. Selenium administration in addition to acrylamide showed significant decrease in aspartateaminotransferase, alanine-aminotransferase, significant elevation in serum total protiens, albumin, globulin and significant increase in serum urea, creatinine, and uric acid levels comparing to acrylamide treated group. There was significant decrease in malondialdehyde level in acrylamide+sodium selenite treated group comparing to acrylamide treated group Conclusion: It was established that oral acrylamide adminstration induced destructive effects in the liver and kidneys, and selenium administration during exposure to acrylamide
\end{abstract}


offers protection against its damaging effect. Recommendations: Acrylamide caused a potential risk for a series of crucial damage, So, Limitation of using acrylamide in our food and screening of its harmful effects occupationally is very important. Also, raising the awareness among population about its hazardous effects.

KEYWORDS: Acrylamide, Selenium, Liver, kidney, Millard reaction.

\section{INTRODUCTION}

Acrylamide (ACR) is known toxin among toxic substances affecting humans all over the world. Acrylamide usually originate in carbohydrate rich foods with low protein component during different processes like frying, baking, roasting and extrusion, including fried potatoes, potato chips, coffee and cereals that are cooked under high temperature (heated to temperatures above $160^{\circ} \mathrm{C}$ ) where the Maillard reaction occurs producing acrylamide (Saleh et al., 2017) \& (Nisreen et al., 2017).

Maillard reaction: first investigated between sugars and amino acids by Louis Camille Maillard (1878-1936). It is often defined as nonenzymatic browning reaction. While foods are processed or cooked at high temperature, a chemical reaction occurs between amino acids and reducing sugars which generate different flavours and brown colour (Tamanna and Mahmood, 2015).

"Potential human carcinogen" this was declared about Acrylamide in 1994 by the International Agency for Research on Cancer. The Scientific Committee on Toxicity supported this finding (Hogervorst et al., 2010). Acrylamide usually found in all kind of foods such as meat, bread and potato products which prepared at high temperatures $\left(>160^{\circ}\right.$ c). Relatively small amounts can be detected in microwaved and boiled foods, but not fresh ones (Bagdonaite, 2007).

Acrylamide is even found in roasted tea leaves and roasted barley grains in the concentration up to 570 and $320 \mathrm{ng} / \mathrm{g}$ respectively. Acrylamide content has a tendency to increase with time of cooking and temperature in both commercially processed foods the same as in home-cooked meals. There are a strong correlation between both the surface color of the food and acrylamide content in food: the darker the surface, the more acrylamide it contains (Bagdonaite, 2007).

Coffee contains high level of acrylamide and whose with high coffee consumption are at risk of acrylamide toxicity. During the process of coffee roasting; large amount of acrylamide form at the initial stage are delivered and quickly reach its maximum level (Mojska and Gielecinska, 2013).

Moreover, oxidative stress for long time produces endogenous acrylamide development under classic physiological conditions $\left(37{ }^{\circ} \mathrm{C}, \mathrm{pH}\right.$ 7.4) where the majority of ACR was conjugated with glutathione while a minimal amount was activated through glycidamide (Saleh et al., 2017).

Liver is considered a major organ for detoxifying body chemicals; also play an important role in the regulation of most metabolites concentration, mainly glucose and amino acids, Serum AST and ALT activity are used as most 
sensitive biomarkers in diagnosis of liver diseases (Alwan et al, 2016).

Kidneys eliminate residual products (urea, creatinin, uric acid, etc.) from the body. Kidneys get rid of toxic materials and excess liquid via 1.5 liter urine. Kidney function disorder is resulted as accumulation of toxic substances in the blood that should be removed from the body (Shivaraj et al., 2010).

Assessment of kidney functions is carried out through blood and urine tests. Such tests indicate to what extent kidneys are successful to filtrate these residual products. As filtration process of kidneys decreases, the levels of these residual products increase in the blood. Kidney diseases are determined if abnormal results are found (Yener et al., 2016).

When toxicity occurs it interrupts a characteristic capability of both liver and kidneys (e.g. Cessation of bile flow, impairment of kidney proximal tubular function), other pathologies induced from toxicant that can occur in any body tissue (e.g. cancer, inflammation, fibrosis) (Burcham $\mathbf{P}$. 2013).

Organs exposed to both highly active uptake processes and heavy blood flows are often vulnerable to toxicity. These considerations are especially important for the liver and kidneys - which as major excretory organs necessarily receive a high blood flow while also strongly expressing many xenobiotic transporters

(Burcham P. 2013).

Another factor that is resulting in liver and kidneys toxicity is the metabolic fate of a chemical. After ACR has been absorbed it is conjugated by glutathione-S-transferase (GST) to N-acetyl- S-(3-amino-3-oxopropyl) cysteine or it reacts with cytochrome
P450 (CYP450) to produce glycidamide. This indicated that liver, kidney GST have significant binding capacity with ACR, with liver GST is three times more efficient in conjugating ACR (Shler et al., 2015).

Both ACR and glycidamide can form covalent adducts with DNA and hemoglobin; this mixture can encourage gene mutation, chromosomal aberration and malignant neoplasm formation. Furthermore, ACR and its bio-transformed metabolite, glycidamide, are damaging to different organs including liver and kidneys (Ghorbel et al., 2015).

Acrylamide, also known as 2propenamide, acrylic-amide, ethylene carbox- amide, propenoic acid amide, vinyl amide, propenamide, acrylamide monomer, is a polar molecule. ACR molecular weight is 71 , a melting point of $84.5 \pm 0.3^{\circ} \mathrm{C}$ and $136^{\circ} \mathrm{C}$ (a high boiling point of at $3.3 \mathrm{kPa}$ ) (Skog and Alexander, 2006). Acrylamide is very soluble in water, alcohols, acetone, acetonitrile, little soluble in ethyl acetate, dichlormethane, diethyl ether. It is insoluble in hexane and other alkanes. It has no significant UVabsorption above $220 \mathrm{~nm}$ and does not fluoresce (Henares et al., 2007).

Acrylamide (ACR) is one of most toxic chemical that is used in wide range in production of polyacrylamides, which furthermore used in dye production, paper formation, plastics manufacture and the handling of water (Nisreen et al., 2017).

There are two pathways ACR pass throw after being taken by the body, the first: glutathione conjugation and the second: is glycidamide epoxidation. ACR conjugate with glutathione-Stransferase then produce $\mathrm{N}$-acetyl cysteine or it can conjugate with 
cytochrome P2E1 and form glycidamide (Mojska and Gielecinska, 2013).

The major mechanism of ACR toxicity is biotransforms to a more potent and highly reactive molecule that starts cellular toxicity. Therefore, the most important pathogenic pathway is the oxidative biotransformation of ACR by cytochrome P450 2E1 (CYP2E1) (Hammad et al., 2013). Glycidamide is the end product. This metabolite derivative (glycidamide) is more reactive towards DNA and proteins than the parental compound, ACR. The major amount of ACR is conjugated with glutathione while a lesser amount is activated via glycidamide (Shler et al., 2015).

Lipid peroxidation, one of the oxidative stress effects, in which oxidative deterioration of lipids yield reactive oxygen species (ROS). Malondialdehyde (MDA) is a chief lipid peroxidation product that has an important role in the estimation of oxidative stress (Kopanska et al., 2017).

In oxidative stress there is a failed oxidant/antioxidant balance as a result of the oxidants leading to significant increase of reactive oxygen radicals (ROS) and decrease in cell antioxidant levels. So, oxidative damages take place in the structural tiny molecules of cells such as lipid, protein, carbohydrate and DNA, because ROS cannot be detoxified as usual (Altinoz and Turkoz, 2014).

Superoxide anion (O2-) which considered one of the main and most important compound shares in the focal levels of oxidative stress that destruct biomembranes, nucleic acid, and enzyme inhibition, protein degradation and lipid peroxidation.
MDA reacts with vascular proteins, e.g. collagen, and leads to deviations in their structure (Petlevski et al., 2006).

Selenium; is an essential natural antioxidant, Selenium shares in the processes of gluthation-SH-peroxidase, the selenoenzyme that catalyses has the power to control lipid peroxidation process through two ways which is control both lipid and hydrogen peroxides process through the first and so decrease the harmful properties of lipid peroxidation. The end result will be decreasing of unsaturated fatty acids and decreasing erythrocytes destruction. Selenium guards both cells and cell membranes from harmful effects of oxidative processes, allowing reaction between oxygen and hydrogen and ions pass through membrane (Teodor et al., 2011).

In the past few years, supplements have attracted the attention of many people especially these with antioxidant properties. These dietary supplements can reduce the harmful effects on human who daily exposed to in their daily diet. Selenium is very important to the living organisms, mainly through its presence in selenoproteins including glutathione peroxidases, thioredoxin reductases and iodothyronine deiodinases (Moghadaszadeh et al., 2006).

\section{MATERIALS AND METHODS \\ Materials: \\ 1. CHEMICALS \\ AND \\ 1) Acrylamide A9099 (ACR):} PREPARATION

A colorless, odorless, has high ability of water solubility formed from the hydration of acrylonitrile. Its molecular weight is $71.079 \mathrm{~g} / \mathrm{mol}$ and 
CAS No. is 79-06-1. It was obtained from Sigma-Egypt (Eltayaran st., Nasr city-Cairo).

2) Sodium selenite:

It is white to yellow powder, soluble in water. It was obtained from Sigma-Egypt Company (Eltayaran st., Nasr city-Cairo).

\section{EXPERIMENTAL ANIMALS AND DESIGN}

The experiment was carried out on 24 adult male albino rats with average weight of (150-200) gm. with average age of 50-60 days; they were gotten from the Animal House in Faculty of Medicine Zagazig University. They were kept under hygienic conditions and fed on a balanced diet and water.

Environmental factors:

The study was performed at the Animal House and laboratories of Faculty of Medicine, Zagazig University. It was performed in accordance with the direction of ethical committee for research on laboratory animals.

\section{Methods:}

(1) Study design:

The rats were classified into 4 groups as the following: Group I (negative control group) (6 rats): 6 rats are fed on routine diet and water to evaluate the basic values of performed tests for 8 weeks. Group II (Sodium selenite treated group) (6 rats): Each rat gavaged orally with $1 \mathrm{mg} / \mathrm{kg}$ body weight Sodium selenite once daily for 8 weeks (Teodor et al., 2011). Group III (Acrylamide treated group) (6 rats): Each rat gavaged orally with $15 \mathrm{mg} / \mathrm{kg}$ body weight ACR (1/10 LD 50, which is $150 \mathrm{mg} / \mathrm{kg}$ in rats by oral dose) (Zenick et al., 1986) once daily for 8 weeks. Group IV (Acrylamide and
Sodium selenite treated group) (6 rats): Each rat gavaged orally with $(1 \mathrm{mg} / \mathrm{kg}$ body weight Sodium selenite then 15 $\mathrm{mg} / \mathrm{kg}$ body weight Acrylamide) once daily for 8 weeks.

(2) Sampling:

After 8 weeks (24 hours from the last dose) animals of the four groups were exposed to:

Blood sample:

Venous blood samples were withdrawn through capillary glass tubes from the plexus in the retro-orbital area below effect of light ether anesthesia as described by (Nemzeket al, 2001). Three $\mathrm{ml}$ of blood were collected from each rat in clean centrifuge tube and incubated at $37^{\circ} \mathrm{C}$ until blood clotted and then centrifuging take place to separate the serum.

\section{Liver and kidney samples:}

The rats were anesthetized by ether after that were sacrificed. The liver and kidney were dissected and examined under light microscope to detect histopathological changes, liver and kidney specimens were fixed in $10 \%$ formalin.

(3) Biochemical analysis:

- Aspartate-aminotransferase (AST) and alanine-aminotransferase (ALT): The estimation was carried out according to the method originally developed by (Reitman and Frankel 1957).

- Total protiens: The total protein was determined by Biuret method explained by (Tietz 1986).

- Albumin and Globulin: were determined according to method of (Doumas et al., 1971). 
- Urea: was determined according to method of Diacetylmonoxine of (Natelson et al., 1964).

- Creatinine: was determined according to method of (Follin and Wu, 1919).

- Uric acid: was determined according to method of (Caraway, 1955).

(4) Histopathological studies:

The liver and kidneys were as usually handled and cutted in sections the thickness of each slice is about 4-5 $\mathrm{mm}$. Then put each section of tissues on a slide, deparaffinized and stained with Hematoxylin and Eosin. Examination of the tissues slides is done through using a light microscope at magnifications X100 and X400 (Bancroft and Stevens, 1997).

(5) Determination of tissue Malondialdehyde (MDA):

The weight of both liver and kidneys were measured and the both organs were homogenized using $0.9 \%$ saline concentration (the times of the volume is 9:1). This $10 \%$ homogenate pass to centrifuging process for $10 \mathrm{~min}$ $(1800 \mathrm{~g} / \mathrm{min})$ and the supernatant was diluted with 10 times of the volume of $0.9 \%$ saline to $1 \%$ concentration (AlSerwi and Ghoneim, 2015).

After obtaining the supernatants we added to it $2.5 \mathrm{~mL}$ of $20 \%$ TCA and 1 $\mathrm{mL}$ of $0.67 \%$ TBA. At $100 \mathrm{C}$ for $30 \mathrm{~min}$ colour of TBA appeared in water. When temperature descends to room temperature, we added $4 \mathrm{~mL}$-butanol then forcelly shake it then centrifuged until pink colour of butanol layer (secondary product of MDA) appeared. The absorption of this endproduct is measured spectrophotometrically at 532 nm wavelength (El-beltagi and Mahgoub, 2016).

(6) Statistical analysis

The collected data of laboratory investigations were coded. The data was entered and analyzed using Microsoft software programs (Excel and SPSS version 20.0 Statistical Package for the Social Sciences). The testes used are as the following: the first one was ANOVA test (measure the differences between multiple means), we set $\mathrm{P}$ value at $<0.05$ for significant results. The second test was paired categorical variables were compared using paired $t$ test.

\section{RESULTS \\ 1. Biochemical analysis:}

As comparing the results of Aspartate aminotransferase and Alanine aminotransferase $(\mathrm{ng} / \mathrm{ml})$ of the negative control group I and the sodium selenite group II there was no statistically significant difference between them ( $p>0.05)$. However, the serum Aspartate aminotransferase and Alanine aminotransferase level mean values of Acrylamide treated group III showed a significant increase $(\mathrm{p}<0.05)$ compared to both control group I and sodium selenite treated group II. Also there was a significant increase $(p<0.05)$ in aspartate aminotransferase and alanine aminotransferase levels mean values of acrylamide \& sodium selenite treated group IV compared with both control group I and sodium selenite treated group II. At the same time there was a significant decrease $(p<0.05)$ in aspartate aminotransferase 
and alanine aminotransferase level mean values of acrylamide \& sodium selenite treated group IV compared with those of acrylamide treated group III (Table 1).

As comparing the results of total protiens, albumin, globulin, urea, creatinine and uric acid $(\mathrm{ng} / \mathrm{ml})$ of the negative control group I and the sodium selenite group II there was no statistically significant difference between them $(p>0.05)$. However, the serum total protiens, albumin, globulin, urea, creatinine and uric acid levels mean values of acrylamide treated group III showed a significant decrease $(p<0.05)$ compared to both control group I and sodium selenite treated group II. Also there was a significant decrease $(\mathrm{p}<0.05)$ in total protiens, albumin, globulin, urea, creatinine and uric acid levels mean values of acrylamide \& sodium selenite treated group IV compared with both control group I and sodium selenite treated group II. At the same time there was a significant increase $(p<0.05)$ in total protiens, albumin, globulin, urea, creatinine and uric acid level mean values of acrylamide \& sodium selenite treated group IV compared with those of acrylamide treated group III (Table 1). 
Table (1): Statistical comparison between mean values of aspartate-aminotransferase (AST), alanineaminotransferase (ALT), total protiens, Albumin, Globulin, urea, creatinine, and uric acid (ng/ml) in group I (A) (-ve control), group II (Sodium selenite), group III (Acrylamide) and group IV(Acrylamide \& Sodium selenite) after 8 weeks of treatment using ANOVA (analysis of variance) test and least significant difference test (LSD):

\begin{tabular}{|c|c|c|c|c|c|c|}
\hline $\begin{array}{c}\text { Group } \\
(n=6)\end{array}$ & $\begin{array}{l}\text { Group I } \\
\text { (A) } \\
\text { (-ve } \\
\text { control) }\end{array}$ & $\begin{array}{l}\text { Group II } \\
\text { (Sodium } \\
\text { selenite) }\end{array}$ & $\begin{array}{c}\text { Group III } \\
\text { (Acrylamide) }\end{array}$ & $\begin{array}{l}\text { Group IV } \\
\text { (Acrylamide } \\
\text { \& Sodium } \\
\text { selenite) }\end{array}$ & $\mathbf{F}$ & $\mathbf{p}$ \\
\hline $\begin{array}{l}\text { Aspartate- } \\
\text { aminotransfe } \\
\text { rase (AST): } \\
(\mathbf{n g} / \mathbf{m l}) \\
\text { Mean } \pm S D\end{array}$ & $33.2 \pm 1.76^{c d}$ & $34.9 \pm 2.27^{\mathrm{cd}}$ & $43.6 \pm 1.63$ abd & $37.5 \pm 1.01^{\mathrm{abc}}$ & 41.786 & $<0.001 *$ \\
\hline $\begin{array}{l}\text { Alanine- } \\
\text { aminotransfe } \\
\text { rase (ALT): } \\
(\mathbf{n g} / \mathbf{m l}) \\
\text { Mean } \pm S D\end{array}$ & $23.3 \pm 0.7^{\mathrm{cd}}$ & $23.5 \pm 0.93^{\text {cd }}$ & $32.8 \pm 1.26^{\mathrm{abd}}$ & $26.15 \pm 0.86^{\mathrm{abc}}$ & 128.26 & $<0.001 *$ \\
\hline $\begin{array}{l}\text { Total } \\
\text { protiens: } \\
\text { (ng/ml) } \\
\text { Mean } \pm S D\end{array}$ & $6.8 \pm 0.35^{\mathrm{cd}}$ & $7 \pm 0.26^{\mathrm{cd}}$ & $5.5 \pm 0.40^{\text {abd }}$ & $5.9 \pm 0.17^{a b c}$ & 32.507 & $<0.001 *$ \\
\hline $\begin{array}{l}\text { Albumin: } \\
\text { (ng/ml) } \\
\text { Mean } \pm S D\end{array}$ & $4.1 \pm 0.19^{\mathrm{cd}}$ & $4.1 \pm 0.28^{\mathrm{cd}}$ & $2.98 \pm 0.177^{\text {abd }}$ & $3.7 \pm 0.17^{\mathrm{abc}}$ & 38.313 & $<0.001 *$ \\
\hline $\begin{array}{l}\text { Globulin } \\
(\mathbf{n g} / \mathbf{m l}) \\
\text { Mean } \pm S D\end{array}$ & $2.96 \pm 0.23^{\mathrm{cd}}$ & $3.01 \pm 0.15^{\mathrm{cd}}$ & $1.66 \pm 0.266^{\mathrm{abd}}$ & $2.2 \pm 0.27 \mathrm{abc}$ & 46.691 & $<0.001 *$ \\
\hline $\begin{array}{l}\text { Urea } \\
(\mathbf{n g} / \mathbf{m l}) \\
\text { Mean } \pm S D\end{array}$ & $48.25 \pm 0.53^{\mathrm{cd}}$ & $48.4 \pm 0.35^{\text {cd }}$ & $35.3 \pm 0.34^{\mathrm{abd}}$ & $41.3 \pm 0.7^{\mathrm{abc}}$ & 939.63 & $<0.001 *$ \\
\hline $\begin{array}{l}\text { Creatinine } \\
(\mathbf{n g} / \mathbf{m l}) \\
\text { Mean } \pm S D\end{array}$ & $0.74 \pm 0.02^{\text {cd }}$ & $0.74 \pm 0.025^{c d}$ & $0.5 \pm 0.015^{\text {abd }}$ & $0.64 \pm 0.018^{a b c}$ & 167.35 & $<0.001 *$ \\
\hline $\begin{array}{l}\text { Uric acid } \\
(\mathbf{n g} / \mathbf{m l}) \\
\text { Mean } \pm S D\end{array}$ & $4.15 \pm 0.17^{\mathrm{cd}}$ & $4.05 \pm 0.22^{\mathrm{cd}}$ & $2.85 \pm 0.09^{\mathrm{abd}}$ & $3.56 \pm 0.11^{\mathrm{abc}}$ & 86.816 & $<0.001 *$ \\
\hline
\end{tabular}

n: Number of rats in each group. SD: Standard Deviation. * *: highly significant $(<0.001)$.

$\mathbf{a}=$ significant with group I

$\mathbf{c}=$ significant with group III

$\mathbf{b}=$ significant with group II

$\mathbf{d}=$ significant with group IV 
2. Histopathological results (Light microscopic examination of $H \& E$ stained sections):

\section{Liver}

Grouop I, II:

The microscopic examination of $H \& E$ stained sections of the liver of the control rats showed normal histology of a hepatic lobule (Fig. 1a).

Group III (Acrylamide treated group):

The liver showed obvious congestion associated with wide spread marked vacuolar degeneration as well as foci of spotty necrosis. Some scattered apoptotic bodies and short fibrous septae (Fig. 1b, c).

Group IV (Acylamide and selenium treated group):

The liver showed moderate congestion and wide spread moderate hydropic degeneration (Fig. 1d).

Sever histopathological changes in the liver observed to be significant higher $(83.3 \%)$ ( $\mathrm{p}<0.001)$ in acrylamide treated group compared to control group, sodium selenite treated group and sodium selenite+ acrylamide treated group (Table 2).

\section{Kidney:}

Group I, II:

The kidney of control rats showed normal histology of a glomeruli and renal tubules (Fig. 2a).

Group III (Acrylamide treated group):

The kidney showed marked congestion, marked hydropic (Vacuolar) degeneration of tubular epithelium and focal prominent tubular necrosis (Fig. 2b, c).

Group IV (Acrylamide and selenium treated group):

The kidney demonstrated early hydropic and moderate vacuolar degeneration (Fig. 2d).

Sever histopathological changes in the kidney observed to be significant higher $(66.7 \%)(\mathrm{p}<0.001)$ in acrylamide treated group compared to control group, sodium selenite treated group and sodium selenite+ acrylamide treated group (Table 3). 


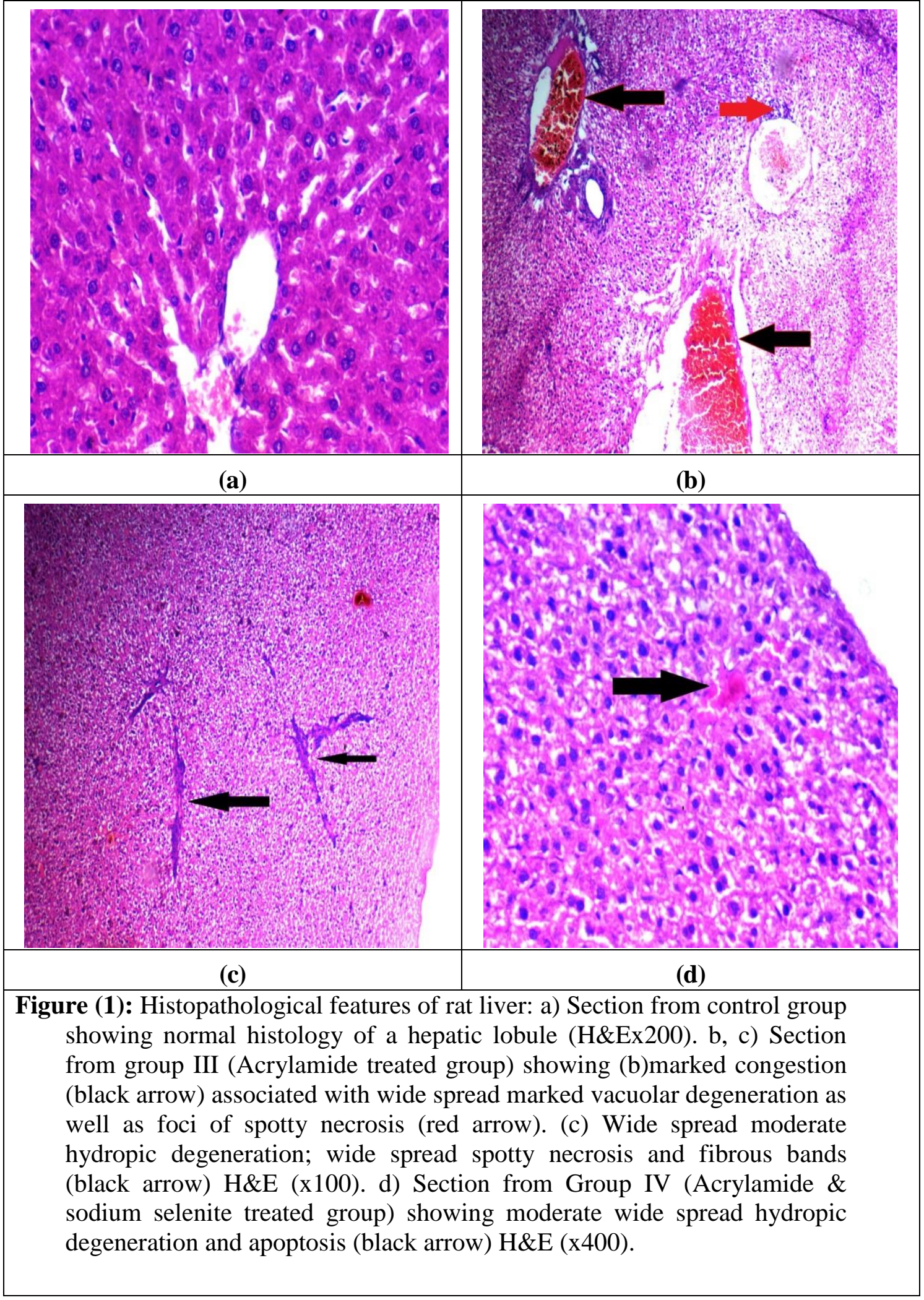




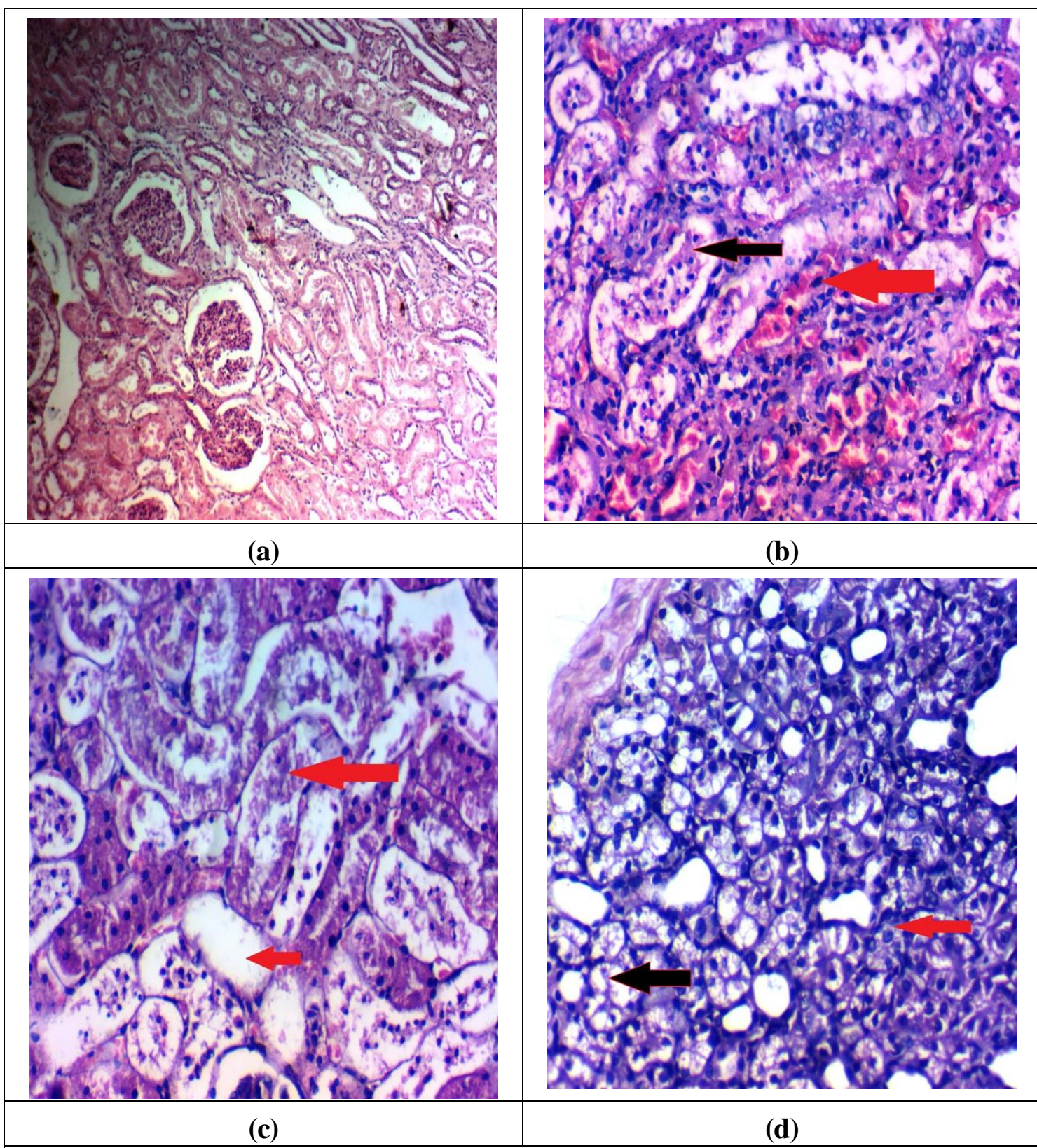

Figure (2): Histopathological features of rat kidney: a) Section from control group showing normal histology of a glomeruli and renal tubules (H\&EX200). b, c) Section from group III (Acrylamide treated group) showing (b) marked congestion(red arrow) and focal early tubular necrosis (black arrow). (c) Prominent tubular necrosis (red arrow) H\&E (x400). d) Section from Group IV (Acrylamide \& sodium selenite treated group) showing early hydropic (red arrow) and moderate vacuolar degeneration (black arrow) H\&E (x200). 
Table (2): Statistical comparison illustrating histopathological changes in the liver among studied groups: group I (A) (-ve control), group II (Sodium selenite), group III (Acrylamide) and group IV(Acrylamide \& Sodium selenite) after 8 weeks of treatment using Fisher exact test:

\begin{tabular}{|c|c|c|c|c|c|c|c|c|c|c|}
\hline \multirow[t]{2}{*}{ Variables } & \multicolumn{2}{|c|}{$\begin{array}{l}\text { Group I } \\
\text { (A) (-ve } \\
\text { control) }\end{array}$} & \multicolumn{2}{|c|}{$\begin{array}{l}\text { Group II } \\
\text { (Sodium } \\
\text { selenite), }\end{array}$} & \multicolumn{2}{|c|}{$\begin{array}{l}\text { Group III } \\
\text { (Acrylamide) }\end{array}$} & \multicolumn{2}{|c|}{$\begin{array}{l}\text { Group } \\
\text { IV(Acrylamide } \\
\text { \& Sodium } \\
\text { selenite) }\end{array}$} & \multirow[t]{2}{*}{$\chi^{2}$} & \multirow[t]{2}{*}{$\mathbf{P}$} \\
\hline & No & $\%$ & No & $\%$ & No & $\%$ & No & $\%$ & & \\
\hline $\begin{array}{l}\text { Histopathological } \\
\text { changes } \\
\text { NO } \\
\text { Mild } \\
\text { Moderate } \\
\text { Sever }\end{array}$ & $\begin{array}{l}6 \\
0 \\
0 \\
0\end{array}$ & $\begin{array}{l}100 \\
0 \\
0 \\
0\end{array}$ & $\begin{array}{l}6 \\
0 \\
0 \\
0\end{array}$ & $\begin{array}{l}100 \\
0 \\
0 \\
0\end{array}$ & $\begin{array}{l}0 \\
0 \\
1 \\
5\end{array}$ & $\begin{array}{l}0 \\
0 \\
16.7 \\
83.3\end{array}$ & $\begin{array}{l}0 \\
5 \\
1 \\
0\end{array}$ & \begin{tabular}{|l}
0 \\
83.3 \\
16.7 \\
0
\end{tabular} & 44 & $<0.001 *$ \\
\hline
\end{tabular}

*: highly significant $(<0.001)$.

Table (3): Statistical comparison illustrating histopathological changes in the kidney among studied groups: group I (A) (-ve control), group II (Sodium selenite), group III (Acrylamide) and group IV(Acrylamide \& Sodium selenite) after 8 weeks of treatment using Fisher exact test:

\begin{tabular}{|c|c|c|c|c|c|c|c|c|c|c|}
\hline \multirow[t]{2}{*}{ Variables } & \multicolumn{2}{|c|}{$\begin{array}{l}\text { Group I } \\
\text { (A) (-ve } \\
\text { control) }\end{array}$} & \multicolumn{2}{|c|}{$\begin{array}{l}\text { Group } \\
\text { II } \\
\text { (Sodium } \\
\text { selenite) }\end{array}$} & \multicolumn{2}{|c|}{$\begin{array}{l}\text { Group III } \\
\text { (Acrylamide) }\end{array}$} & \multicolumn{2}{|c|}{$\begin{array}{l}\text { Group IV } \\
\text { (Acrylamide } \\
\text { Sodium selenite) }\end{array}$} & \multirow[t]{2}{*}{$\chi^{2}$} & \multirow[t]{2}{*}{$\mathbf{P}$} \\
\hline & No & $\%$ & No & $\%$ & No & $\%$ & No & $\%$ & & \\
\hline $\begin{array}{l}\text { Histopathologi } \\
\text { cal changes } \\
\text { NO } \\
\text { Mild } \\
\text { Moderate } \\
\text { Sever }\end{array}$ & $\begin{array}{l}6 \\
0 \\
0 \\
0\end{array}$ & $\begin{array}{l}100 \\
0 \\
0 \\
0\end{array}$ & $\begin{array}{l}6 \\
0 \\
0 \\
0\end{array}$ & $\begin{array}{l}100 \\
0 \\
0 \\
0\end{array}$ & $\begin{array}{l}0 \\
0 \\
2 \\
4\end{array}$ & $\begin{array}{l}0 \\
0 \\
33.3 \\
66.7\end{array}$ & $\begin{array}{l}1 \\
4 \\
1 \\
0\end{array}$ & $\begin{array}{l}16.66 \\
66.7 \\
16.66 \\
0\end{array}$ & 37.13 & $<0.001 *$ \\
\hline
\end{tabular}

\section{Malondialdehyde in liver and kidneys}

Liver:

In liver tissue, malondialdehyde was increased in acrylamide group (III) mean $\pm \mathrm{SD}(6.133 \pm 0.24)$ in comparison to control group (I) mean \pm SD (1.56 \pm 0.159 ) showing a significant difference. Comparing the control groups (I,), and selenium group (II) mean \pm SD (1.48 \pm 0.21 ) there was no significant different inbetween (Table 4). In group IV (Acrylamide and selenium), moderate elevation of MDA level were seen mean \pm SD $(2.37 \pm 0.149)$ (Table 4). There was a statistically significant difference between groups $(\mathrm{p}<0.001)$.

\section{Kidneys:}

In kidney tissue, malondialdehyde was elevated in acrylamide group (III) mean \pm SD (4.28 \pm 0.21$)$ in comparison to control group (I) mean $\pm \mathrm{SD}(0.81 \pm 0.134)$ showing a significant difference. Comparing the control groups (I,), and selenium group (II) mean $\pm \mathrm{SD}(0.73 \pm$ 0.197 ) there was no significant different in-between (Table 4). In group IV (Acrylamide and selenium), moderate 
elevation of MDA level were seen mean \pm statistically significant difference between SD (2 \pm 0.129$)$ (Table 4). There was a groups $(\mathrm{p}<0.001)$

Table (4): Statistical comparison between mean values of malondialdehyde in liver and kidney in group I (A) (-ve control), group II (Sodium selenite), group III (Acrylamide) and group IV(Acrylamide \& Sodium selenite) after 8 weeks of treatment using ANOVA (analysis of variance) test and least significant difference test (LSD):

\begin{tabular}{|c|c|c|c|c|c|c|}
\hline $\begin{array}{l}\text { Group } \\
(n=6)\end{array}$ & $\begin{array}{l}\text { Group I } \\
(- \text { ve } \\
\text { control) }\end{array}$ & $\begin{array}{l}\text { Group II } \\
\text { (Sodium } \\
\text { selenite) }\end{array}$ & $\begin{array}{c}\text { Group III } \\
\text { (Acrylamide) }\end{array}$ & $\begin{array}{c}\text { Group IV } \\
\text { (Acrylamide } \\
\text { \& Sodium } \\
\text { selenite) }\end{array}$ & $\mathbf{F}$ & $\mathbf{p}$ \\
\hline $\begin{array}{l}\text { Malondialde } \\
\text { hyde in liver: } \\
\text { (nmol/mg) } \\
\text { Mean } \pm S D\end{array}$ & $1.56 \pm 0.159^{\mathrm{cd}}$ & $1.48 \pm 0.21^{\mathrm{cd}}$ & $6.133 \pm 0.24$ abd & $2.73 \pm 0.149$ abc & 765.25 & $<0.001 *$ \\
\hline $\begin{array}{l}\text { Malondialde } \\
\text { hyde in } \\
\text { kidney: } \\
\text { (nmol/mg) } \\
\text { Mean } \pm S D\end{array}$ & $0.81 \pm 0.134^{\text {cd }}$ & $0.73 \pm 0.197^{\mathrm{cd}}$ & $4.28 \pm 0.211^{\text {abd }}$ & $2 \pm 0.129$ abc & $\mathbf{5 5 7 . 5 8}$ & $<0.001 *$ \\
\hline
\end{tabular}

n: Number of rats in each group. SD: Standard Deviation. *: highly significant $(<0.001)$. a $=$ significant with group I $\mathbf{c}=$ significant with group III

\section{DISCUSSION}

In our experimental model, acrylamide treatment caused an oxidative stress in tissues. Serum hepatic and renal markers were significantly modulated by applied dose of acrylamide. Some ultrastructural changes developed in a tissue.

There was a significant rise in serum AST and ALT activities. These results are parallel to those verified by Yousef and El-Demerdash (2006) in serum and plasma of mice and rats respectively after toxicity with ACR. These results confirmed by the suggestion that recorded by Chinoy and Memon (2001) who recognized the significant rise in serum AST, ALT levels and related it with the bipolar nature of ACR, it is described as followings: the $\mathrm{CH} 2=\mathrm{CH}$ part of $\mathrm{ACR}$ experience hydrophobic interactions at the same time the $\mathrm{CONH} 2$ part of ACR induce hydrogen bonds linked to cell structures. This bipolar property aggravate ACR ability to change the component structure of cell membrane and affect liver parenchymal cell membrane which increase its permeablity, thereby producing the active holding of enzymes and making them appear first in the extracellular space and then in the blood. The previous changes confirmed by histopathological changes (El- Bohi et al., 2011).

Ammonia is originated from tissues and food proteins. Urea is produced in the liver from ammonia. There were observed significant declines in serum urea levels. The reduced urea levels may be a result of impaired urea synthesis due to hepatic 
inadequacy because of liver damage (ALMosaibih, 2013).

Our results agree with the results of Alturfan et al., (2011) who stated that there is a significant decrease in uric acid. It was establish that ACR stops urate absorption and so leading to urate diuresis. This will end in reduction of serum uric acid levels. A low serum urate concentration result from decreased production or increased excretion and since xanthine oxidase, (the enzyme responsible for conversion of oxypurines to uric acid), is found in a large amount in the liver and the mucosa of the small intestines, the enzymes rate of formation may decrease due to necrosis in multiple sections of liver.

The results come to an agreement with those of Khalil (2005) results as he stated that the levels of uric acid significantly show decrease in groups that fed with potato chips and toasted bread in their food as an important and major source of ACR.

Defect of hepatic cells and liver damage are the main cause of reductions of total protein, albumin, and globulin levels this is due to hypoproteinaemia. Liver damage appeared as fatty vacuolation in cytoplasm and centrilobular hepatocytes necrosis with lymphocytic infiltration. The same result reported by Asha et al. (2008): a steady decline in levels of hepatic protein with ACR administration resulted from stunted protein synthesis, alteration in protein metabolism, or to the escape of protein stored in hepatocytes.

Our results disagree with results of Allam et al. (2010) who stated that there is decrease in ALT and AST levels in the acrylamide treated group which was due to decreased endogenous production or increased destruction.
Our results agree with the results of Ozer et al., (2014) who stated that there are ultrastructural changes in epithelial cells of proximal tubules inside the kidney segments. As well as enhanced vacuolization and extensively distributed peroxisomes was found in the cytoplasm of epithelial cells. Degenerating cells with electron dense cytoplasm and swollen mitochondria were noticed.

As the liver and kidneys are the main sites of detoxification of toxic materials in human body so multiple degenerative changes observed in this study indicate the local effect of ACR (Shler et al., 2015).

Hammad et al. (2013) stated that there was degeneration of the glomerular tuft with infiltration of lymphocytes found in the kidneys of the rats treated with ACR. Vacuolation of renal tubules and loss of their brush borders; degenerative changes can be noticed in their epithelial lining accompanied by damage of the cells, necrosis, and congestion of the interstitial blood vessels.

The liver of experimental rats presented with degenerative changes of the hepatocytes, congestion of the blood vessels including portal vein and infiltration of moderate mononuclear inflammatory cells. Necrosis affects most of the hepatocytes (Shler et al., 2015).

Totani et al., (2007) stated that the kidneys revealed infiltration of mononuclear inflammatory cells and some cell lining of renal tubules show degenerative changes, others showed necrosis. These findings may be due to the fact that kidneys are the route of excretion of ACR and its metabolites.

Lipid peroxyl radicals proliferate into malondialdehyde (MDA) that is a sign of the oxidative damage of proteins and lipoproteins which is a potential 
mechanism for liver and kidney destruction (Shler et al., 2015).

In the present work we observed an elevation in MDA level with acrylamide administration which agrees with the results of El-beltagi and Mahgoub (2016), who stated that there were increases in MDA Level induced by ACR signifying that ACR caused oxidative effects in the liver and other organs such as brain and testes.

Selenium is merged into proteins to create selenoproteins, one of the most important antioxidant enzymes [especially, glutathione peroxidase (GSH$\mathrm{Px})$ ]. One of the characters of the antioxidant selenoproteins is to help prevent cellular damage from free radicals (Sadeghian et al., 2012).

Free radicals are ordinary by-products of oxygen metabolism that expected to develop chronic diseases. Se as a component of GSH-Px significantly increased GSH and GSH-Px levels and partially prevent the biochemical variations of the rats which exposed to ACR. The administration of $\mathrm{Se}$, as a component of GSH-Px in combination with ACR has the ability to significally decrease lipid peroxidation, and enhanced glutathione levels (Ali et al., 2014).

\section{CONCLUSIONS}

From the previous results of the present study it has been determined that the acrylamide harmfully upset liver and kidney through its lipid peroxidation reaction, and afterwards the irregular disturbance of liver and kidney function parameters. Supplementation of selenium during acrylamide exposure banned the biochemical and histopathological changes in rats for some extent and may have protective effects against liver and kidney dysfunction.

\section{RECOMMENDATIONS}

As Acrylamide offers a potential toxicity profile and health threatening features, so, we recommend restriction of acrylamide exposure either occupationally or in food containing product. Administration of selenium may guard from the adverse effects of ACR.

\section{REFERENCES}

Ali M., Aly E., and Elawady A. (2014): Effectiveness of selenium on acrylamide toxicity to retina. Int J Ophthalmol. 7(4): 614-620.

Allam A.A., El-Ghareeb A.W., AbdulHamid M. Bakery A.E., Gad M. and Sabri M. (2010): Effect of prenatal and perinatal acrylamide on the biochemical and morphological changes in liver of developing albino rat. Arch. Toxicol. 84: 129-141.

AL-Mosaibih M.A. (2013): Effects of monosodium glutamate and acrylamide on the liver tissue of adult Wistar rats. Life Sci. J. 10(2s): 3542.

Al-Serwi R. and Ghoneim F. (2015): The impact of vitamin $\mathrm{E}$ against acrylamide induced toxicity on skeletal muscles of adult male albino rat tongue: Light and electron microscopic study. Journal of Microscopy and Ultrastructure 3: 137-147.

Altinoz E. and Turkoz Y. (2014): The Protective Role of NAcetylcysteine against AcrylamideInduced Genotoxicity and Oxidative Stress in Rats. Gene Therapy and Molecular Biology. 16: 35-43.

Alturfan E.I., Beceren A., ehirli A.O., Demiralp Z.E., ener G., and Omurtag G.X (2011): Protective 
effect of Nacetyl- L-cysteine against acrylamideinduced oxidative stress in rats Turk. J. Vet. Anim. Sci. 36: 438- 445.

Alwan N., Alkalby J. and Al-Masoudi E. (2016): Effect of acrylamide on thyroid and liver functions in adult male rats. Indo- Asian Journal of Multidisciplinary Research. 2(4):673-680.

Asha S., Renu S. and Jyotsna J. (2008): Biochemical changes in the liver of Swiss albino mice orally exposed to acrylamide. Mj. Int. J. Sci. Tech. 2:542-550.

Bagdonaite K. (2007): Acrylamide in foods In Formation of Acrylamide during Roasting of Coffee. 2-10.

Bancroft and Stevens (1997): Theory and practice of histological techniques. The journal of pathology.183(2): 243-244.

Burcham P. (2013): Target-Organ Toxicity: Liver and Kidney. An Introduction to Toxicology: 151187.

Caraway W. (1955): Epidemiology of chronic Rheumatism, American Journal of Clinical Pathology. 25: 840.

Chinoy N. J. and Memon, M. R. (2001): Beneficial effects of some vitamins and calcium on fluoride and aluminium toxicity of gastrocnemius muscle and liver of male mice. Fluoride; 34: 21-33.

Doumas B., Watson W. and Biggs $H$. (1971): Albumin standards and the measurement of serum albumin with bromocresol green. Clinical Chimical. Acta, 31:87-96.
El-beltagi H. and Ahmed M. (2016): Assessment The Protective Role of Quercetin on Acrylamide-Induced Oxidative Stress in Rats. Journal of food biochemistry. 1745-4514.

El- Bohi K., Moustafa G., El sharkawi N. and Sabik L. (2011): Genotoxic Effects of Acrylamide in Adult Male Albino Rats Liver. Journal of American Science. 7(1): 1097-1108.

Faabhaea K. (2005): Effect of dietary acrylamide formed in potato crisps and toasted bread on rats. Egypt. J. Nat. Toxins, 2: 57-70.

Follin R. and Wu H. (1919): System of blood analysis. J. Biol and Chem. 32. 81-86.

Ghorbel I, Maktouf S, Kallel C., Chaabouni S., Boudawara T. and Zeghal N. (2015): Disruption of Erythrocyte Antioxidant Defence System, Hematological Parameters, Induction of Proinflammatory Cytokines and DNA Damage in Liver of co-exposed rats to Aluminum and Acrylamide. Chemico- Biological Interaction. 236: 31-40.

Hammad A., Osman M., Abdelgadir W. (2013): Effects of acrylamide toxicity on growth performance andserobiochemisty of Wistar rats. Br. J. Pharmacol. Toxicol. 4: 163168.

Hogervorst J, Baars B, Schouten L. , Konings E., Goldbohm A. and, Brandt P. (2010): The carcinogenicity of dietary acrylamide intake: a comparative discussion of epidemiological and experimental animal research. critical reviews in toxicology. 23(2): 145-160. 
Kopanska M, Czech J, Zagata P., Dobrek L., Thor P. and Formicki G. (2017): Effect Of The Different Doses Of Acrylamide On Acetylocholinoesterase Activity, Thiol Groups, Malondialdehyde Concentrations In Hypothalamus And Selected Muscles Of Mice. Journal of physiology and pharmacology. 68(4): 565-571.

Moghadaszadeh B. and Beggs AH (2006): Selenoproteins and their impact on human health through diverse physiological pathways, Physiology. 21: 307-15.

Mojska H and Gielecinska I (2013): Studies of Acrylamide Level in Cofee and coffee Substitutes Influence of Raw Material and Manufacturing Conditions. Rocz Panstw Zakl Hig. 64(3): 173-181.

Natelson S., Israel S., and John E. (1964): Improvement in the method of separation of guanidine organic acid by column chromatography ;isolation and identification of guanidinosuccinic acid from human urine. Microchemical Journal 8: 371-382.

Nemzek J, Bolgos G, Williams, B et al (2001): Differences in normal values for murine white blood cell counts and other hematological parameters based on sampling site. Inflammation Research. 50: 523527.

Nisreen A, Rajeh P, and Khayyat D (2017): Effect of the combined administration of vitamin-E and 5aminosalicylic acid on acrylamideinduced testicular toxicity. Journal of Taibah University Medical Sciences. 12(5): 445-454.
Özer E., Ucar G., Helvacioğlu F., Aldemir D. and Turkoglu S. (2014): Effect of Acrylamide Treatment on Arginase Activities and Nitric Oxide Levels in Rat Liver and Kidney. Acta Medica Mediterranea. 30: 375-382.

Petlevski R, Juretic D, Hadžija M., Slijepčevic $M$. and Bajalo $J$. (2006): Concentration of malondialdehyde in a Nod mice treated with acarbose. Biochemia Medica.16(1):43-9.

Reitman S. and Frankel S. (1957): A colorimetric method for determination of serum glutamate oxaloacetate and glutamic pyruvate transaminase. Am. J. Clin. Pathol. 28: 56-58.

Rufian A., Arribas G., and Morales F. (2007): Acrylamide content of selected Spanish foods: Survey of biscuits and bread derivatives. Food Addit. Contam. 24(4): 343-350.

Sadeghian S., Kojouri GA., and Mohebbi A. (2012): Nanoparticles of Selenium as Species with stronger physiological effects in sheep in comparison with sodium selenite. Biol Trace Elem Res. 146(3):302-308.

Saleh A, Shahin M, and Kelada $\mathbf{N}$ (2017): Hepatoprotective effect of taurine and coenzyme Q10 and their combination against acrylamide-induced oxidative stress in rats. Tropical Journal of Pharmaceutical Research August. 16 (8): 1849-1855.

Shivaraj G., Prakash B., Shruthi S., Vinayak V., Avinash A., and Sonal N. (2010): Markers of renal function tests.N Am J Med Sci. 2(4): 170-173. 
Shler A, Kawa A., and Shilan F. (2015): Effect of Acrylamide on Liver and Kidneys in Albino Wistar Rats. Int.J.Curr.Microbiol.App.Sci. 4(5): 434-444.

Skog K. and Alexander J. (2006): Acrylamide and other hazardous compounds in heat-treated foods. Woodhead Publishing Limited, Cambridge, England.

Tamanna N. and Mahmood N. (2015): Food Processing and Maillard Reaction Products: Effect on Human Health and Nutrition. International journal of food science. 2015:1-6.

Teodor V, Cuciureanu M. and Slencu B. (2011): Potential Protective Role of Selenium in Acrylamide Intoxication. A Biochemical Study. Studia Universitatis "Vasile Goldiş", Seria Ştiinţele Vieţii. 21(2): 263-268.
Tietz, N. (1986): Textbook of Clinical Chemistry, W.B. Saunders, Philadelphia, PA.

Totani N., Yawata M., Ojiri Y. and Fujioka Y. (2007): Effects of trace acrylamide in-take in Wistar rats. J. Oleo Sci. 56: 501-506.

Yener Y., Humeyra F., Toker A. (2016): Evaluation of Some Renal Function Parameters in Rats Treated with Acrylamide. ARC Journal of Animal and Veterinary Science. 2(1): 1-8.

Yousef M.I. and El-Demerdash F.M. (2006): Acrylamide-induced oxidative stress and biochemical perturbations in rats. Toxicology ;219( 1-3): 133-41.

Zenick H., Hope E. and Smith M. K. (1986): Reproductive toxicity associated with acrylamide treatment in male and female rats. J. Toxicol. Environ. Health, 17: 457. 


\section{الدور الوقائي المحتمل للسيلينيوم على الإجهاد التأكسدي الناتج عن الأكريلاميد في الجرذان:

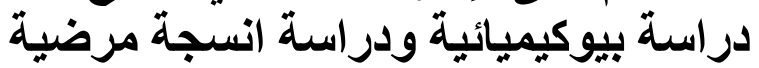

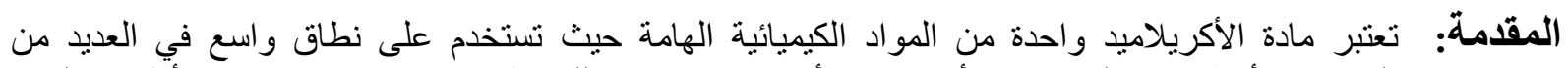

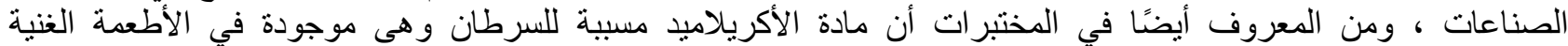
بالكربو هيدرات المستهلكة ، مثل البطاطا المقلية ورقائق البطاطس.

الهدف: الهدف من هذا العمل هو اكتثاف تأثثير ات الأكريلاميد على الكبد والكلى فى ذكور الجرذان البيضاء البالغة وتقييم دور الحماية للسيلينيوم. الكني.

طريقة البحث:أجريت هذه الدراسه على عدد 24من ذكور الجرذان البيضاء البالغة مقسمة الى 4مجمو عات كالآتي:

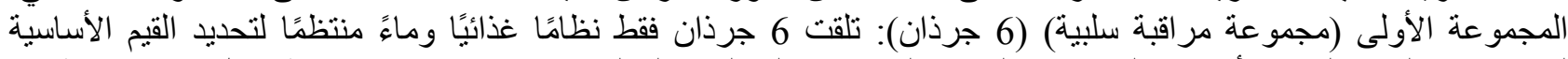

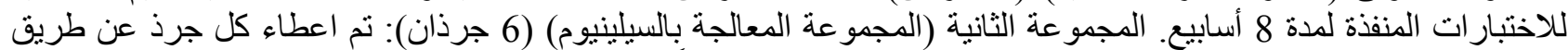

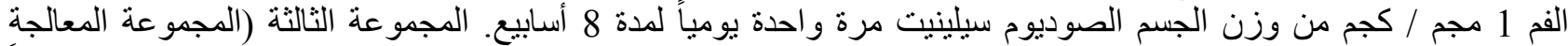

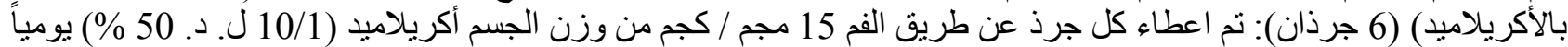

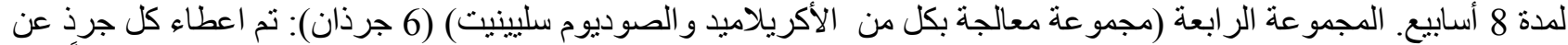

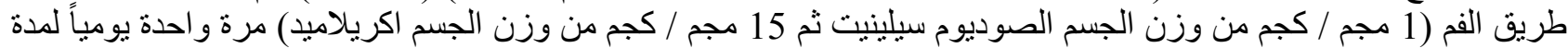

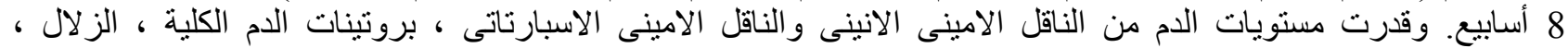

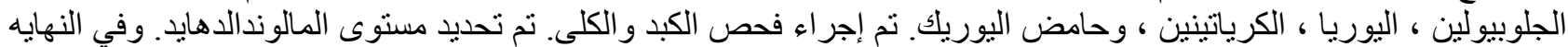

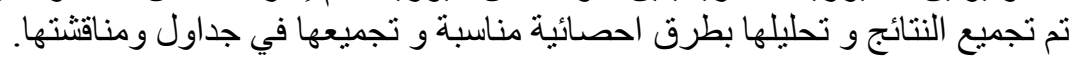

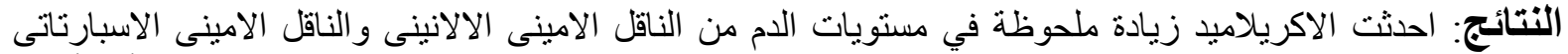

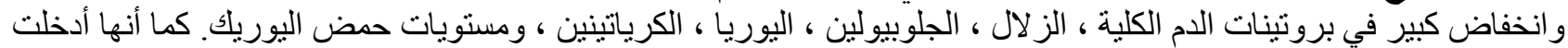
تغييرات الأنسجة المرضية في الكبد والكلى مع زيادة مستوى المالوندالدهيد حيث كان هنالك فرق ذاتين ذو دلالة إلحصائية بين

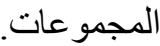

الاستتتاج: أثتبت هذه الدراسة ان تناول الاكريلاميد عن طريق الفم يؤدى الى احداث تأثأثيرات مدمرة في الكبد والكليتين

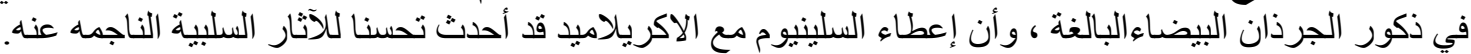

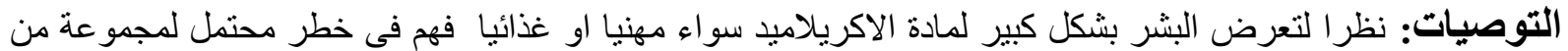

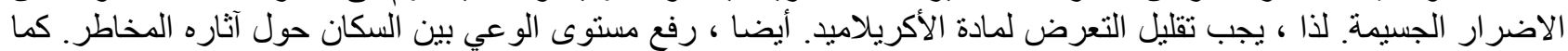

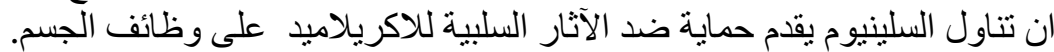

